\title{
Regionalization and Home Bias: The Case of Canada
}

\author{
Janet Ceglowski \\ Bryn Mawr College
}

\begin{abstract}
The bilateral trade flows between Canada and the US have grown rapidly in the 1990s. Are they evidence of an emerging North American trading bloc? A gravity model of trade finds that while economic size and proximity can explain much of the substantial trade between Canada and the US, the US bias in Canada's merchandise trade has grown since the formation of the Canada-US Free Trade Area. The rise in the US bias reflects an emerging gap between Canada's home bias relative to the US and its home bias relative to the other major industrial countries.
\end{abstract}

- JEL Classification: F15, F14

- Key Words: Canada, United States, Trade, Integration

\section{Introduction}

In value terms, the bilateral trade flows between the US and Canada are the largest in the world. In the years after the Canada-US Free Trade Area (FTA) was established, they grew faster than Canada's overall trade; US-bound exports rose from $73 \%$ of Canada's total exports in 1988 to $81 \%$ in 1996 while imports from the US rose from $66 \%$ to $68 \%$ of Canada's total imports over the same period. Are these growing bilateral trade flows evidence of an emerging North American trading bloc?

\footnotetext{
*Corresponding Address: Department of Economics, Bryn Mawr College, Bryn Mawr, PA 19010, USA Phone: +610-526-5182, Fax: +610-526-7475, Email: jceglows@brynmawr.edu

${ }^{1}$ See Frankel (1997) for a summary of much of this research.

Acknowledgements: I would like to thank Caroline Freund and Kerry Odell for helpful comments, and the Canadian Studies Grants Program for financial support. This research was begun while I was a visiting scholar at the Federal Reserve Bank of Philadelphia. The views expressed here do not necessarily reflect those of the Federal Reserve Bank of Philadelphia or the Federal Reserve System.
} 
Recent empirical research has applied gravity models to bilateral trade flows, finding evidence of regional concentration in trade among countries located in particular parts of the world or participating in specific preferential trading arrangements. But most of this work has either excluded the members of the North American Free Trade Area (NAFTA) from consideration or found no statistically significant impact of membership in the FTA or NAFTA on bilateral trade patterns. ${ }^{1}$ Both researchers omission of the NAFTA from consideration and the apparent insignificance of an intra-regional trade bias among the NAFTA countries could be rooted in a decided lack of degrees of freedom in measuring regionalization within NAFTA. Any analysis of country-level data is hindered by the fact that the NAFTA includes only three countries and dates back to only 1994. Its precursor, the FTA, dates to 1989 but includes only two countries. Anderson and Smith (1999) avoid this problem by using subnational trade data to investigate a possible US bias in Canada's international trade. Evidence that Canada trades more with the US than with other countries of comparable size and proximity would indicate the existence of a US bias. Surprisingly, Anderson and Smith find no evidence of a US bias in Canada's trade for 1988.

Yet the issue is worth revisiting with data from the period since the formation of the FTA. Anderson and Smith's analysis is based on Canada's bilateral trade patterns in the year before the free trade agreement took effect. If the FTA and NAFTA have fostered continental economic integration, findings for 1988 may not hold for trade in the 1990s. In that case, a further question is whether any emerging regionalization reflects a fall in the economic borders between the members of the free trade area or a rise in the economic borders between members and non-members.

The assessment of an intra-regional trade bias among the largest North American economies is important for evaluating both the global scope of regionalization and the trade impacts of the recent free trade agreements between Canada, the US, and Mexico. This paper provides one part of that assessment by evaluating the US bias in Canada's trade in the post-FTA period. The primary question it addresses is whether the US bias has increased since the formation of the free trade area. Accordingly, its main focus is on a possible change in Canada's US bias, rather than the level of the bias. It finds evidence that the US bias in Canada's trade has risen since the creation of the free trade area. The rise in the US bias is traced to divergent changes in Canada's home bias with respect to the US and its home bias with respect to other industrialized countries. 


\section{The Model and Data}

This analysis uses the gravity model approach employed in recent empirical studies of regionalization and home bias. ${ }^{2}$ The gravity model specifies trade between two locations as a function of the distance between them and their economic sizes. The further apart two locations are, the greater the transportation and information costs between them so that bilateral exports are expected to be inversely related to the distance between locations. Conversely, the gravity model predicts that larger economies will engage in higher levels of trade so bilateral exports should be positively related to the economic sizes of the exporting and importing locations. Thus, the basic form of the gravity equation can be expressed in log-linear form as:

$$
x_{i j}=\beta_{0}+\beta_{1} y_{i}+\beta_{2} y_{j}+\beta_{3} \text { distance }_{i j}+e_{i j}
$$

where $x_{i j}=\operatorname{logarithm}$ of exports of goods from location $i$ to location $j(i \neq j)$

$y_{i}$ and $y_{j}=\operatorname{logarithms}$ of gross domestic product for locations $i$ and $j$

distance $_{i j}=$ logarithm of the distance in miles from the economic center of $i$ to the economic center of $j$.

Since the question at hand concerns a possible US bias in Canadian trade, the dependent variable must differentiate Canada's trade with the US from its international trade with other countries. Estimating the home bias in Canadian trade necessitates a second distinction between Canada's internal trade and its international trade. Thus the analysis requires three categories of Canadian trade: trade within Canada; trade between Canada and the US; and trade between Canada and the rest of the world. Though it is possible to use country-level data to derive measures of these three categories of trade, they would yield only one observation each for internal trade and Canada-US trade for a given time period. This would make it difficult to estimate the degree of home or US bias with precision. ${ }^{3}$ Instead, this analysis applies the gravity model to an expanded version

\footnotetext{
${ }^{2}$ The gravity model is an established empirical model of bilateral trade. See Frankel (1997) for a thorough review of the origins of the gravity model and Frankel (1997) and Deardorff (1998) for a discussion of its relation to international trade theories.

${ }^{3}$ Wei (1996) encounters this problem when using measures of internal trade constructed from countrylevel data to gauge home bias for individual countries. Because the use of country-level data also requires a single measure of distance for all trade between two countries, it could make it difficult to provide meaningful measures of the distance variable. This is especially true for Canada's internal trade and its bilateral trade with the US because of the large variations in distance between economic hubs in the two-country region.
} 
of the subnational Canadian trade data first employed by McCallum (1995). The source of these data is a unique set of provincial trade accounts for Canada, which provides estimates of both interprovincial and total international merchandise trade for each of Canada's provinces and territories. When combined with bilateral international trade data for Canada, these measures yield estimates of each province's bilateral exports to and imports from other individual provinces (province-province trade), individual US states (province-state trade), and individual countries other than the US (province-country trade). ${ }^{4}$

Two dummy variables are added to the simple specification in (1) in order to distinguish these three categories of provincial trade flows. Specifically, PP takes the value of 1 for trade between two provinces and PS takes the value of 1 for trade between a province and a state. By default, the control group is trade between a province and a country other than the US. The coefficient on PP therefore measures the density of Canada's internal trade relative to its trade with countries other than the US. The coefficient on PS captures the density of provincial trade with the US relative to that between provinces and the rest of the world. Because of the size of the US economy and its proximity to Canada, one would expect the two countries to engage in relatively extensive trade. Since the gravity equation explicitly controls for economic size and geographic distance, the coefficients on PP and PS measure the province-province and province-state trade in excess of the levels predicted by these factors and Canada's average provincecountry trade. As such, these two coefficients provide estimates of the home and US biases in Canadian trade vis-à-vis countries other than the US. The equation to be estimated is:

$$
x_{i j}=\beta_{0}+\beta_{1} y_{i}+\beta_{2} y_{j}+\beta_{3} \text { distance }_{i j}+\beta_{4} P P+\beta_{5} P S+e_{i j}
$$

where each trading pair $(i, j)$ consists of one Canadian province and either a province, state, or country.

As explained above, $\beta_{1}$ and $\beta_{2}$ are expected to be positive and $\beta_{3}$ should be negative. To the extent that provincial trade exhibits home bias relative to province-country trade, $\beta_{4}$ should be positive. Likewise, $\beta_{5}$ will be positive if Canada's international trade is biased toward the US.

For the purposes of this analysis, data for the 10 Canadian provinces are combined with a sample of 30 states and 18 industrial countries. The states are those originally used by McCallum (1995); they represent the 10 states that border

\footnotetext{
${ }^{4}$ Appendices 1 and 2 contain a full description of all the data used in the analysis.
} 
Canada plus the 20 non-bordering states with the largest populations in 1988. The countries chosen for the analysis are 18 industrial countries: Australia, Austria, Belgium, Denmark, Finland, France, Germany, Ireland, Italy, Japan, the Netherlands, New Zealand, Norway, Portugal, Spain, Sweden, Switzerland, and the UK. Together with the US, these countries accounted for about $90 \%$ of Canadas merchandise imports and exports in 1988. Thus the data consist of bilateral trade flows for $90(10 \times 9)$ province-province pairs, $600(10 \times 30 \times 2)$ province-state pairs, and $360(10 \times 18 \times 2)$ province-country pairs for a total of 1050 observations, less observations for which recorded bilateral trade flows are zero.

Economic activity in the exporting and importing locations is measured as the Canadian dollar value of the appropriate measure of output; gross provincial product is used for provinces, gross state product for states, and gross domestic product for countries. The latter two measures are converted to Canadian dollar terms using average annual exchange rates. For each trading pair, distance is measured as the great circle distance between the relevant economic centers.

The analysis examines data for five years: 1988, 1990, 1992, 1994, and 1996. This sample period is dictated by data availability. The first year, 1988, is the initial period for which detailed data on provincial trade with US states are available. It is also the year before the FTA went into effect and a year analyzed by McCallum (1995), Helliwell (1996, 1998), and Anderson and Smith (1999) in their studies of Canada's home bias. The final year, 1996, is the last year for which interprovincial trade data are available.

\section{Estimation and Results}

The ordinary least squares estimates of equation (2) indicate that economic size and distance play significant roles in Canada's bilateral trade that show little variation over time (Table 1, equation 1). The coefficients on both income variables are just over 1 , larger than most estimates from gravity equations based on country-level data but on a par with the estimates from the studies of Canada's home bias based on subnational data. ${ }^{5}$ The same is true of the coefficient on distance, which indicates that a $1 \%$ increase in the distance between a province

\footnotetext{
${ }^{5}$ Some gravity equations include terms for per capita output. When added to (2), the per capita output terms were estimated with coefficients that varied in sign and were statistically insignificant in three of the five equations. Other studies that have employed Canadian provincial trade data report similar findings and the per capita terms are not included in the estimations reported here.
} 
Table 1. Gravity Equation Estimates: (1988-96)

\begin{tabular}{|l|c|c|c|c|c|c|c|c|c|c|}
\hline & \multicolumn{7}{|c|}{ Equation 1} & \multicolumn{5}{c|}{ Equation 2} \\
\hline Year & 1988 & 1990 & 1992 & 1994 & 1996 & 1988 & 1990 & 1992 & 1994 & 1996 \\
\hline \multirow{2}{*}{$\mathrm{y}_{\mathrm{i}}$} & $1.15^{*}$ & $1.15^{*}$ & $1.16^{*}$ & $1.15^{*}$ & $1.18^{*}$ & $1.14^{*}$ & $1.15^{*}$ & $1.16^{*}$ & $1.14^{*}$ & $1.17^{*}$ \\
& $(.03)$ & $(.03)$ & $(.03)$ & $(.03)$ & $(.03)$ & $(.03)$ & $(.03)$ & $(.03)$ & $(.03)$ & $(.03)$ \\
\hline \multirow{2}{*}{$\mathrm{y}_{\mathrm{j}}$} & $1.11^{*}$ & $1.12^{*}$ & $1.13^{*}$ & $1.13^{*}$ & $1.18^{*}$ & $1.10^{*}$ & $1.11^{*}$ & $1.12^{*}$ & $1.12^{*}$ & $1.18^{*}$ \\
& $(.03)$ & $(.03)$ & $(.03)$ & $(.03)$ & $(.03)$ & $(.03)$ & $(.03)$ & $(.03)$ & $(.03)$ & $(.03)$ \\
\hline \multirow{2}{*}{ distance $_{\mathrm{ij}}$} & $-1.30^{*}$ & $-1.29^{*}$ & $-1.31^{*}$ & $-1.29^{*}$ & $-1.33^{*}$ & $-1.14^{*}$ & $-1.13^{*}$ & $-1.15^{*}$ & $-1.15^{*}$ & $-1.18^{*}$ \\
& $(.07)$ & $(.07)$ & $(.07)$ & $(.07)$ & $(.07)$ & $(.07)$ & $(.08)$ & $(.08)$ & $(.08)$ & $(.08)$ \\
\hline \multirow{2}{*}{ PP } & $3.02^{*}$ & $3.16^{*}$ & $3.28^{*}$ & $3.27^{*}$ & $3.32^{*}$ & $3.08^{*}$ & $3.22^{*}$ & $3.35^{*}$ & $3.33^{*}$ & $3.38^{*}$ \\
& $(.16)$ & $(.17)$ & $(.17)$ & $(.17)$ & $(.18)$ & $(.16)$ & $(.17)$ & $(.17)$ & $(.17)$ & $(.18)$ \\
\hline \multirow{2}{*}{ PS } & -0.11 & -0.001 & 0.13 & 0.19 & $0.28^{* *}$ & 0.03 & 0.14 & $0.27 \#$ & $0.32^{* *}$ & $0.41^{*}$ \\
& $(.13)$ & $(.14)$ & $(.14)$ & $(.13)$ & $(.13)$ & $(.13)$ & $(.15)$ & $(.14)$ & $(.14)$ & $(.14)$ \\
\hline \multirow{2}{*}{ ADJACENT } & & & & & & $0.93^{*}$ & $0.93^{*}$ & $0.91^{*}$ & $0.83^{*}$ & $0.88^{*}$ \\
& & & & & & $(.19)$ & $(.20)$ & $(.20)$ & $(.20)$ & $(.21)$ \\
\hline Observations & 1038 & 1036 & 1043 & 1041 & 1041 & 1038 & 1036 & 1043 & 1041 & 1041 \\
\hline Adjusted $\mathrm{R}^{2}$ & 0.75 & 0.71 & 0.74 & 0.75 & 0.75 & 0.76 & 0.72 & 0.75 & 0.75 & 0.75 \\
\hline SEE & 1.243 & 1.408 & 1.315 & 1.286 & 1.313 & 1.231 & 1.397 & 1.305 & 1.277 & 1.303 \\
\hline
\end{tabular}

Notes : All equations are estimated with ordinary least squares and include constant terms. Standard errors have been corrected for heteroskadasticity and are reported in parentheses. *, $* *$ and \# indicate statistical significance at the $1 \%, 5 \%$, and $10 \%$ error levels. $P P$ is a dummy variable taking the value 1 for trade between provinces. $P S$ is a dummy variable taking the value 1 for trade between a province and a state.

and its trading partner leads to a $1.3 \%$ decrease in their bilateral trade. The coefficient on $P P$ is positive and significant, implying that Canadian provinces trade between $20.5(\exp 3.02)$ and $28(\exp 3.32)$ times more with one another than with (non-US) countries of equal distance and economic size. The coefficient on $P S$ is small and negative in the regressions for 1988 and 1990, suggesting that there is no significant US bias in Canada's trade. In fact, the negative sign on PS implies a larger home bias vis-à-vis the US compared to the other countries in the sample. This finding and the associated point estimates for the home and US biases are consistent with Anderson and Smith (1999), who report no evidence of a positive US bias in Canada's trade for 1988. However the coefficient on PS is positive in the other three regressions and statistically significant in the estimate for 1996, indicating that in 1996 trade between Canada and the US was about $30 \%$ higher than that between Canada and the other industrial countries in the sample. 
Table 2. Seemingly Unrelated Regressions

\begin{tabular}{|c|c|c|c|c|c|c|c|c|c|c|c|c|}
\hline & \multicolumn{6}{|c|}{ Equation 1} & \multicolumn{6}{|c|}{ Equation 2} \\
\hline Year & 1988 & 1990 & 1992 & 1994 & 1996 & $\begin{array}{l}\text { Pooled- } \\
\text { sample }\end{array}$ & 1988 & 1990 & 1992 & 1994 & 1996 & $\begin{array}{l}\text { Pooled- } \\
\text { sample }\end{array}$ \\
\hline $\mathrm{y}_{\mathrm{i}}$ & $\begin{array}{c}1.07 * \\
(.02)\end{array}$ & $\begin{array}{l}1.07^{*} \\
(.02)\end{array}$ & $\begin{array}{l}1.07^{*} \\
(.02)\end{array}$ & $\begin{array}{l}1.07^{*} \\
(.02)\end{array}$ & $\begin{array}{l}1.07 * \\
(.02)\end{array}$ & $\begin{array}{l}1.07 * \\
(.02)\end{array}$ & $\begin{array}{l}1.06^{*} \\
(.02)\end{array}$ & $\begin{array}{l}1.06^{*} \\
(.02)\end{array}$ & $\begin{array}{l}1.06^{*} \\
(.02)\end{array}$ & $\begin{array}{l}1.06^{*} \\
(.02)\end{array}$ & $\begin{array}{l}1.06^{*} \\
(.02)\end{array}$ & $\begin{array}{l}1.06^{*} \\
(.02)\end{array}$ \\
\hline $\mathrm{y}_{\mathrm{j}}$ & $\begin{array}{c}1.04 * \\
(.03)\end{array}$ & $\begin{array}{l}1.05^{*} \\
(.03) \\
\end{array}$ & $\begin{array}{l}1.06^{*} \\
(.03) \\
\end{array}$ & $\begin{array}{l}1.06^{*} \\
(.03) \\
\end{array}$ & $\begin{array}{l}1.12^{*} \\
(.03)\end{array}$ & $\begin{array}{l}1.06^{*} \\
(.02)\end{array}$ & $\begin{array}{l}1.04 * \\
(.03)\end{array}$ & $\begin{array}{l}1.04 * \\
(.03)\end{array}$ & $\begin{array}{l}1.05^{*} \\
(.03)\end{array}$ & $\begin{array}{l}1.06^{*} \\
(.03)\end{array}$ & $\begin{array}{l}1.11^{*} \\
(.03)\end{array}$ & $\begin{array}{l}1.05^{*} \\
(.02)\end{array}$ \\
\hline distance $_{\mathrm{ij}}$ & \begin{tabular}{|c|}
$-1.28 *$ \\
$(.06)$
\end{tabular} & $\begin{array}{r}-1.28 \\
(.06)\end{array}$ & $\begin{array}{r}-1.28 \\
(.06)\end{array}$ & $\begin{array}{r}-1.28 \\
(.06)\end{array}$ & $\begin{array}{c}-1.28^{*} \\
(.06)\end{array}$ & $\begin{array}{c}-1.28^{*} \\
(.06)\end{array}$ & $\begin{array}{c}-1.11^{*} \\
(.07)\end{array}$ & $\begin{array}{l}-1.11 * \\
(.07)\end{array}$ & $\begin{array}{c}-1.11 * \\
(.07)\end{array}$ & $\begin{array}{c}-1.11^{*} \\
(.07)\end{array}$ & $\begin{array}{c}-1.11^{*} \\
(.07)\end{array}$ & $\begin{array}{c}-1.11 * \\
(.07)\end{array}$ \\
\hline PP & $\begin{array}{c}2.81^{*} \\
(.17) \\
\end{array}$ & $\begin{array}{r}2.96^{*} \\
(.19) \\
\end{array}$ & $\begin{array}{c}3.07^{*} \\
(.18) \\
\end{array}$ & $\begin{array}{c}3.08^{*} \\
(.17) \\
\end{array}$ & $\begin{array}{l}3.15^{*} \\
(.18) \\
\end{array}$ & $\begin{array}{c}2.96^{*} \\
(.16) \\
\end{array}$ & $\begin{array}{r}2.89^{*} \\
(.17) \\
\end{array}$ & $\begin{array}{r}3.03 * \\
(.19) \\
\end{array}$ & $\begin{array}{l}3.14 * \\
(.18) \\
\end{array}$ & $\begin{array}{l}3.15^{*} \\
(.17) \\
\end{array}$ & \begin{tabular}{|l}
$3.22^{*}$ \\
$(.18)$ \\
\end{tabular} & $\begin{array}{l}3.03^{*} \\
(.16) \\
\end{array}$ \\
\hline PS & $\begin{array}{c}-0.20 \# \\
(.11)\end{array}$ & $\begin{array}{r}-0.07 \\
(.12)\end{array}$ & $\begin{array}{l}0.06 \\
(.12)\end{array}$ & $\begin{array}{l}0.14 \\
(.11)\end{array}$ & $\begin{array}{c}0.25^{* * *} \\
(.12)\end{array}$ & $\begin{array}{c}-0.01 \\
(.11)\end{array}$ & $\begin{array}{c}-0.05 \\
(.11)\end{array}$ & $\begin{array}{l}0.08 \\
(.12)\end{array}$ & $\begin{array}{c}0.21 \# \\
(.12)\end{array}$ & $\begin{array}{c}0.29 * * \\
(.12)\end{array}$ & $\begin{array}{l}0.40^{*} \\
(.12)\end{array}$ & $\begin{array}{l}0.14 \\
(.11)\end{array}$ \\
\hline $\begin{array}{l}\text { ADJA- } \\
\text { CENT }\end{array}$ & & & & & & & $\begin{array}{c}0.96^{*} \\
(.18)\end{array}$ & $\begin{array}{l}0.96^{*} \\
(.18)\end{array}$ & $\begin{array}{c}0.96^{*} \\
(.18)\end{array}$ & $\begin{array}{l}0.96^{*} \\
(.18)\end{array}$ & $\begin{array}{c}0.96^{*} \\
(.18)\end{array}$ & $\begin{array}{c}0.96^{*} \\
(.18)\end{array}$ \\
\hline $\begin{array}{l}\text { Observa- } \\
\text { tions }\end{array}$ & 1024 & 1024 & 1024 & 1024 & 1024 & $5 \times 1024$ & 1024 & 1024 & 1024 & 1024 & 1024 & $5 \times 1024$ \\
\hline $\begin{array}{l}\text { Adjusted } \\
\mathrm{R}^{2}\end{array}$ & 0.75 & 0.70 & 0.73 & 0.74 & 0.73 & $\begin{array}{l}0.75,0.70 \\
0.73,0.74 \\
0.73\end{array}$ & 0.76 & 0.71 & 0.73 & 0.75 & 0.74 & \begin{tabular}{|l}
$0.76,0.71$ \\
$0.73,0.75$ \\
0.73
\end{tabular} \\
\hline SEE & 1.208 & 1.390 & 1.285 & 1.242 & 1.312 & $\begin{array}{l}1.21,1.39 \\
1.29,1.24 \\
1.32\end{array}$ & 1.195 & 1.378 & 1.271 & 1.231 & 1.301 & $\begin{array}{l}1.20,1.38 \\
1.27,1.23 \\
1.31\end{array}$ \\
\hline
\end{tabular}

Notes: For each equation, the first 5 columns report results of an SUR where the coefficients on $y_{i}$, distance, and ADJACENT are constrained to be equal in each sample period. The pooledsample estimates are the results of SURs where all but the constant terms are constrained to be equal. All equations include constant terms. Standard errors are reported in parentheses. *, ** and \# indicate statistical significance at the $1 \%, 5 \%$, and $10 \%$ error levels.

Several variants of the simple specification in (2) were evaluated in turn. A dummy variable for trading partners that share a common border (ADJACENT) was added on the premise that two locations that are adjacent to one another engage in more trade than two that aren't, regardless of the countries in which they are located. The coefficient on ADJACENT is positive and statistically significant, and indicates that the level of trade between a province and a bordering province or state is over twice that between trading pairs that do not share a common border (Table 1, equation 2). The addition of ADJACENT raises the point estimates on PS, indicating a larger US bias after controlling for adjacency. When ADJACENT is included, the US bias becomes statistically significant by 1992 and grows steadily thereafter. According to this specification, 
Canada's trade with the US was about $30 \%$ higher than its trade with the other sample countries in 1992, 38\% higher in 1994, and 50\% higher in $1996 .{ }^{6}$

Two further modifications were motivated by econometric concerns. First, equation (2) was estimated with instrumental variables by using trading partner's populations as instruments for their gross domestic products. This modification was aimed at avoiding possible endogeneity between the income variables and the dependent variable but it made little difference. Second, the five cross-section equations were estimated as seemingly unrelated regressions (SURs). Tests indicated that the coefficients on $y_{i}$, distance, and ADJACENT could reasonably be constrained to be equal across the five sample periods. The point estimates on $P P$ and $P S$ are slightly smaller in the constrained SUR estimates as compared to the least squares estimates, but both sets of estimates show a similar pattern over time (Table 2).

Finally, a pooled-sample estimation was performed to obtain estimates for the average home and US biases (Table 2). The coefficient on $P P$ implies that Canada's interprovincial trade averages 19 to 21 times more than its trade with countries other than the US. The coefficient on PS is small and insignificant, indicating that Canada's trade with the US is, on average, no greater than would be predicted on the basis of the economic characteristics included in the equation and Canada's trade with the other countries in the sample.

\section{The FTA and the US Bias}

A comparison of the estimates for each of the sample years in Tables 1 and 2 reveals a steady increase in the estimated US bias over time. A formal hypothesis test establishes that the coefficient on PS is significantly higher in 1996 than in 1988. ${ }^{7}$ The positive US bias identified in the empirical estimates could reflect the influence of a number of factors including similarities in the cultures, languages, and institutions of Canada and the US, trade links promoted by a history of crossborder investment and migration, and relatively low average tariff rates and other

\footnotetext{
${ }^{6}$ Following Helliwell's (1996) analysis of home bias, a second dummy variable was added to distinguish exporting and importing pairs that are both located on an ocean, on the premise that easy ocean access encourages trade between such pairs. When included, this dummy variable was correctly signed and statistically significant. But its addition led to only a slight improvement in the overall fit of the equation and marginally higher point estimates for $P P$ and $P S$.

${ }^{7} \mathrm{~A} \chi^{2}$ test of the hypothesis that the coefficient on PS in the constrained SUR is the same in 1988 and 1996 is rejected with a p-value of 0.00000 in both versions of (2).
} 
Table 3. Control Group: Province-Province Trade

\begin{tabular}{|c|c|c|c|c|c|c|c|c|c|c|}
\hline & \multicolumn{5}{|c|}{ Equation 1} & \multicolumn{5}{|c|}{ Equation 2} \\
\hline Year & 1988 & 1990 & 1992 & 1994 & 1996 & 1988 & 1990 & 1992 & 1994 & 1996 \\
\hline $\mathrm{y}_{\mathrm{i}}$ & $\begin{array}{l}1.15^{*} \\
(.03)\end{array}$ & $\begin{array}{l}1.15^{*} \\
(.03)\end{array}$ & $\begin{array}{l}1.16^{*} \\
(.03)\end{array}$ & $\begin{array}{l}1.15^{*} \\
(.03)\end{array}$ & $\begin{array}{l}1.18^{*} \\
(.03)\end{array}$ & $\begin{array}{l}1.14^{*} \\
(.03)\end{array}$ & $\begin{array}{l}1.15^{*} \\
(.03)\end{array}$ & $\begin{array}{l}1.16^{*} \\
(.03)\end{array}$ & $\begin{array}{l}1.14^{*} \\
(.03)\end{array}$ & $\begin{array}{l}1.17 * \\
(.03)\end{array}$ \\
\hline $\mathrm{y}_{\mathrm{j}}$ & $\begin{array}{l}1.11 * \\
(.03)\end{array}$ & $\begin{array}{l}1.12 * \\
(.03)\end{array}$ & $\begin{array}{l}1.13^{*} \\
(.03)\end{array}$ & $\begin{array}{l}1.13^{*} \\
(.03)\end{array}$ & $\begin{array}{l}1.18^{*} \\
(.03)\end{array}$ & $\begin{array}{l}1.10^{*} \\
(.03)\end{array}$ & $\begin{array}{l}1.11^{*} \\
(.03)\end{array}$ & $\begin{array}{l}1.12 * \\
(.03)\end{array}$ & $\begin{array}{l}1.12^{*} \\
(.03)\end{array}$ & $\begin{array}{l}1.18^{*} \\
(.03)\end{array}$ \\
\hline distance $_{i j}$ & $\begin{array}{c}-1.30^{*} \\
(.07)\end{array}$ & $\begin{array}{c}-1.29 * \\
(.07)\end{array}$ & $\begin{array}{c}-1.31 * \\
(.07)\end{array}$ & $\begin{array}{c}-1.29^{*} \\
(.07)\end{array}$ & $\begin{array}{c}-1.33^{*} \\
(.07)\end{array}$ & $\begin{array}{c}-1.14 * \\
(.07)\end{array}$ & $\begin{array}{c}-1.13^{*} \\
(.08)\end{array}$ & $\begin{array}{c}-1.15^{*} \\
(.08)\end{array}$ & $\begin{array}{c}-1.15^{*} \\
(.08)\end{array}$ & $\begin{array}{c}-1.18 * \\
(.08)\end{array}$ \\
\hline PS & $\begin{array}{c}-3.13^{*} \\
(.10)\end{array}$ & $\begin{array}{c}-3.16^{*} \\
(.11)\end{array}$ & \begin{tabular}{|c}
$-3.15^{*}$ \\
$(.11)$ \\
\end{tabular} & $\begin{array}{c}-3.08^{*} \\
(.12) \\
\end{array}$ & $\begin{array}{c}-3.05^{*} \\
(.12) \\
\end{array}$ & $\begin{array}{c}-3.05^{*} \\
(.11) \\
\end{array}$ & $\begin{array}{c}-3.08^{*} \\
(.12) \\
\end{array}$ & $\begin{array}{c}-3.08^{*} \\
(.12) \\
\end{array}$ & $\begin{array}{c}-3.01 * \\
(.12) \\
\end{array}$ & $\begin{array}{c}-2.97 * \\
(.13) \\
\end{array}$ \\
\hline PC & $\begin{array}{c}-3.02^{*} \\
(.16)\end{array}$ & $\begin{array}{c}-3.16^{*} \\
(.17)\end{array}$ & $\begin{array}{c}-3.28^{*} \\
(.17)\end{array}$ & $\begin{array}{c}-3.27^{*} \\
(.17)\end{array}$ & $\begin{array}{c}-3.32 * \\
(.18)\end{array}$ & $\begin{array}{c}-3.08^{*} \\
(.16)\end{array}$ & $\begin{array}{c}-3.22 * \\
(.17)\end{array}$ & $\begin{array}{c}-3.35^{*} \\
(.17)\end{array}$ & $\begin{array}{c}-3.33^{*} \\
(.17)\end{array}$ & $\begin{array}{c}-3.38^{*} \\
(.18)\end{array}$ \\
\hline $\begin{array}{l}\text { ADJA- } \\
\text { CENT }\end{array}$ & & & & & & $\begin{array}{l}0.93^{*} \\
(.19)\end{array}$ & $\begin{array}{c}0.93^{*} \\
(.20)\end{array}$ & $\begin{array}{c}0.91 * \\
(.20)\end{array}$ & $\begin{array}{l}0.83^{*} \\
(.20)\end{array}$ & $\begin{array}{l}0.88^{*} \\
(.21)\end{array}$ \\
\hline $\begin{array}{l}\text { Observa- } \\
\text { tions }\end{array}$ & 1038 & 1036 & 1043 & 1041 & 1041 & 1038 & 1036 & 1043 & 1041 & 1041 \\
\hline Adjusted $\mathrm{R}^{2}$ & 0.75 & 0.71 & 0.74 & 0.75 & 0.75 & 0.76 & 0.72 & 0.75 & 0.75 & 0.75 \\
\hline SEE & 1.243 & 1.408 & 1.315 & 1.286 & 1.313 & 1.231 & 1.397 & 1.305 & 1.277 & 1.303 \\
\hline
\end{tabular}

Notes: All equations are estimated with ordinary least squares and include constant terms. Standard errors are reported in parentheses and have been corrected for heteroskadasticity. * indicates statistical significance at the $1 \%$ error level. $P S$ is a dummy variable taking the value 1 for trade between a province and a state. $P C$ is a dummy variable taking the value 1 for trade between a province and a country other than the US.

barriers to bilateral Canada-US trade. However the complete explanation must account for the significant rise in the US bias in the 1990s. The influence of linguistic and other cultural or historic ties on Canada's international trade patterns should be constant over the relatively short time span analyzed here. Thus, while these non-economic factors most likely contribute to the level of the US bias, they cannot explain its increase in the 1990s. ${ }^{8}$ A more likely explanation of the rise in the US bias rests with the formation of the free trade area.

If the FTA has advanced regionalization in North America, it should be evident in a higher point estimate on $P S$ in the period since 1989 than before the free trade

\footnotetext{
${ }^{8}$ To the extent that these non-economic factors are important in explaining Canada's home and US biases, their impact is included in the coefficient estimates for PP and PS reported in Tables 1 and 2. If they were to be explicitly included in (2), the estimated levels of Canada's trade biases would be expected to fall in each of the sample years. So long as the trade impacts of these non-economic factors were constant over the sample period, however, the above conclusions concerning the change in the US bias would still hold.
} 
Table 4. Seemingly Unrelated Regressions Control Group: Province-Province Trade

\begin{tabular}{|c|c|c|c|c|c|c|c|c|c|c|}
\hline & \multicolumn{5}{|c|}{ Equation 1} & \multicolumn{5}{|c|}{ Equation 2} \\
\hline Year & 1988 & 1990 & 1992 & 1994 & 1996 & 1988 & 1990 & 1992 & 1994 & 1996 \\
\hline $\mathrm{y}_{\mathrm{i}}$ & $\begin{array}{l}1.07 * \\
(.02)\end{array}$ & $\begin{array}{l}1.07 * \\
(.02)\end{array}$ & $\begin{array}{l}1.07 * \\
(.02)\end{array}$ & $\begin{array}{l}1.07 * \\
(.02)\end{array}$ & $\begin{array}{l}1.07 * \\
(.02)\end{array}$ & $\begin{array}{l}1.06^{*} \\
(.02)\end{array}$ & $\begin{array}{l}1.06 * \\
(.02)\end{array}$ & $\begin{array}{l}1.06^{*} \\
(.02)\end{array}$ & $\begin{array}{l}1.06^{*} \\
(.02)\end{array}$ & $\begin{array}{l}1.06 * \\
(.02)\end{array}$ \\
\hline$y_{j}$ & $\begin{array}{l}1.04 * \\
(.03)\end{array}$ & $\begin{array}{l}1.05^{*} \\
(.03)\end{array}$ & $\begin{array}{l}1.06^{*} \\
(.03)\end{array}$ & $\begin{array}{l}1.06^{*} \\
(.03)\end{array}$ & $\begin{array}{l}1.12 * \\
(.03)\end{array}$ & $\begin{array}{l}1.04 * \\
(.03)\end{array}$ & $\begin{array}{l}1.04 * \\
(.03)\end{array}$ & $\begin{array}{l}1.05^{*} \\
(.03)\end{array}$ & $\begin{array}{l}1.06^{*} \\
(.03)\end{array}$ & $\begin{array}{l}1.11 * \\
(.03)\end{array}$ \\
\hline distance $_{\mathrm{ij}}$ & $\begin{array}{c}-1.28 * \\
(.06)\end{array}$ & $\begin{array}{c}-1.28 * \\
(.06)\end{array}$ & $\begin{array}{c}-1.28 * \\
(.06)\end{array}$ & \begin{tabular}{|c|}
$-1.28 *$ \\
$(.06)$
\end{tabular} & $\begin{array}{c}-1.28 * \\
(.06)\end{array}$ & \begin{tabular}{|c|}
$-1.11 *$ \\
$(.07)$
\end{tabular} & $\begin{array}{c}-1.11 * \\
(.07)\end{array}$ & $\begin{array}{c}-1.11 * \\
(.07)\end{array}$ & $\begin{array}{c}-1.11 * \\
(.07)\end{array}$ & $\begin{array}{c}-1.11 * \\
(.07)\end{array}$ \\
\hline PS & $\begin{array}{c}-3.02 * \\
(.14)\end{array}$ & $\begin{array}{c}-3.03 * \\
(.16)\end{array}$ & $\begin{array}{c}-3.00^{*} \\
(.15)\end{array}$ & \begin{tabular}{|c|}
$-2.94 *$ \\
$(.14)$
\end{tabular} & $\begin{array}{c}-2.90 * \\
(.15)\end{array}$ & \begin{tabular}{|c|}
$-2.94 *$ \\
$(.14)$
\end{tabular} & $\begin{array}{c}-2.95^{*} \\
(.16)\end{array}$ & $\begin{array}{c}-2.92 * \\
(.15)\end{array}$ & $\begin{array}{c}-2.86^{*} \\
(.14)\end{array}$ & $\begin{array}{c}-2.82 * \\
(.15)\end{array}$ \\
\hline PC & $\begin{array}{c}-2.82 * \\
(.17)\end{array}$ & $\begin{array}{c}-2.96^{*} \\
(.19)\end{array}$ & $\begin{array}{c}-3.07 * \\
(.18)\end{array}$ & \begin{tabular}{|c|}
$-3.08^{*}$ \\
$(.17)$
\end{tabular} & $\begin{array}{c}-3.15^{*} \\
(.18)\end{array}$ & \begin{tabular}{|c|}
$-2.89 *$ \\
$(.17)$
\end{tabular} & $\begin{array}{c}-3.03^{*} \\
(.19)\end{array}$ & $\begin{array}{c}-3.14^{*} \\
(.18)\end{array}$ & $\begin{array}{c}-3.15^{*} \\
(.17)\end{array}$ & $\begin{array}{c}-3.22 * \\
(.18)\end{array}$ \\
\hline $\begin{array}{l}\text { ADJA- } \\
\text { CENT }\end{array}$ & & & & & & $\begin{array}{c}0.96^{*} \\
(.18)\end{array}$ & $\begin{array}{c}0.96 * \\
(.18)\end{array}$ & $\begin{array}{c}0.96^{*} \\
(.18)\end{array}$ & $\begin{array}{c}0.96^{*} \\
(.18)\end{array}$ & $\begin{array}{l}0.96^{*} \\
(.18)\end{array}$ \\
\hline $\begin{array}{l}\text { Observa- } \\
\text { tions }\end{array}$ & 1024 & 1024 & 1024 & 1024 & 1024 & 1024 & 1024 & 1024 & 1024 & 1024 \\
\hline $\begin{array}{l}\text { Adjusted } \\
\mathrm{R}^{2}\end{array}$ & 0.75 & 0.70 & 0.73 & 0.74 & 0.73 & 0.76 & 0.71 & 0.73 & 0.75 & 0.74 \\
\hline SEE & 1.208 & 1.390 & 1.285 & 1.242 & 1.312 & 1.195 & 1.378 & 1.271 & 1.231 & 1.301 \\
\hline
\end{tabular}

Notes: The estimates are the results of SURs where the coefficients on $y_{i}$, distance, and ADJACENT are constrained to be equal in each sample period. All equations include constant terms. Standard errors are reported in parentheses. * indicates statistical significance at the $1 \%$ error level. PS is a dummy variable taking the value 1 for trade between a province and a state. $P C$ is a dummy variable taking the value 1 for trade between a province and a country other than the US.

area was formed. This is precisely what the statistical results reveal. Estimates of the US bias are small and mostly insignificant for 1988, the year before the FTA was established. The same is true for 1990. The absence of a regional bias in these estimates is consistent with the findings of earlier research on Canada-US trade for 1970, 1980, 1990, and 1992 (Frankel and Wei, 1998) and 1988 (Anderson and Smith, 1999). But the results presented here for the period since 1990 contrast with those for earlier years, revealing a statistically significant US bias in Canada's trade as early as 1992. The emergence of a significant regional trade bias in the 1990s coincides with the formation of the FTA, suggesting the free trade area has been a catalyst for the apparent regionalization.

The US bias can be characterized as the difference between Canada's home bias relative to the US and its home bias relative to the other sample countries. The rise 
in the US bias could reflect a decline in Canada's home bias vis-à-vis the US or an increase in Canada's home bias vis-à-vis the other sample countries. ${ }^{9}$ While the former would indicate a growing open-ness to trade between Canada and the US, the latter would suggest regionalization is occurring at the expense of general open-ness. In fact, both effects appear to be operative. This is easiest to see when a dummy variable for province-country trade $(P C)$ replaces $P P$ in equation (2). In this case, the absolute value of the coefficient on $P S$ measures Canada's home bias vis-à-vis the US while that on $P C$ measures its home bias relative to the other sample countries. A comparison of the estimates over time suggests a declining home bias with respect to the US but a rising home bias with respect to the other countries (Tables 3 and 4). In the SUR estimates, the increase in the estimated coefficient on $P C$ indicates the corresponding home bias rose from about 16-to-1 in 1988 to 24 -to-1 in 1996. This increase in PC is statistically significant at the $1 \%$ error level but the fall in PS over the same period is not. ${ }^{10}$ This assigns primary responsibility for the growth in Canada's regional trade bias to a decline in its open-ness to trade with the other industrial countries. As Frankel (1997) notes, trade diversion is an expected outcome of a free trade area when its formation does not involve changes in the level of protection from nonmember imports. However the statistical results suggest the economic border between Canada and the US has fallen marginally at most, despite the rapid growth in the two countries' bilateral trade.

The results reported here are based on the use of the nominal exchange rate for converting the foreign output measures to Canadian dollars. As such, the output variables provide measures of purchasing power. The Canadian dollar depreciated sharply during the 1990s, particularly against several of the European currencies in the sample. This translates into sizable increases in foreign purchasing power when converted to Canadian dollars with the nominal exchange rate. The findings for Canada-US trade imply that the increases in US purchasing power were matched largely by growth in bilateral trade. Thus no significant decline in Canada's home bias with respect to the US is apparent in the estimates. In the case of the other sample countries, the bilateral trade flows did not keep apace of the measured increases in their purchasing power, so the outcome appears as a higher

\footnotetext{
${ }^{9}$ It could also reflect a fall in both measures of home bias but a comparatively larger fall in Canada's home bias vis-à-vis the US.

${ }^{10} \mathrm{~A} \chi^{2}$ test of the hypothesis that coefficient on $P S$ is the same in 1988 and 1996 yields p-value the of 0.009 in both versions of (2) in Table 4. The same test for the coefficient on PS yields p-values of 0.31 in both versions of (2).
} 
home bias.

A measure of economic size that did not include the exchange rate-induced increases in foreign purchasing power could produce different results. However a comparison of Canada's nominal exchange rates with their purchasing power parity (PPP) counterparts from OECD $(1997,1998)$ suggests the Canadian dollar was undervalued by the end of the sample period, substantially so with respect to several European currencies. Ideally, the undervaluation should be included in the gravity equation in order to account for any effects of exchange rate misalignments on bilateral trade patterns. Otherwise, such effects could show up in the home bias estimates instead. One way of including individual roles for both the undervaluation and economic size is to divide the foreign output variable into

Table 5. Gravity Equation Estimates Based on PPP GDPs

\begin{tabular}{|l|c|c|c|c|c|c|c|c|c|c|}
\hline & \multicolumn{7}{|c|}{ Least squares estimates } & \multicolumn{5}{c|}{ SUR estimates } \\
\hline Year & 1988 & 1990 & 1992 & 1994 & 1996 & 1988 & 1990 & 1992 & 1994 & 1996 \\
\hline \multirow{2}{*}{$\mathrm{y}_{\mathrm{i}}$} & $1.16^{*}$ & $1.16^{*}$ & $1.17^{*}$ & $1.16^{*}$ & $1.17^{*}$ & $1.08^{*}$ & $1.08^{*}$ & $1.08^{*}$ & $1.08^{*}$ & $1.08^{*}$ \\
& $(.03)$ & $(.03)$ & $(.03)$ & $(.03)$ & $(.03)$ & $(.02)$ & $(.02)$ & $(.02)$ & $(.02)$ & $(.02)$ \\
\hline \multirow{2}{*}{$\mathrm{y}_{\mathrm{j}}$} & $1.11^{*}$ & $1.12^{*}$ & $1.14^{*}$ & $1.13^{*}$ & $1.18^{*}$ & $1.05^{*}$ & $1.05^{*}$ & $1.07^{*}$ & $1.07^{*}$ & $1.13^{*}$ \\
& $(.03)$ & $(.03)$ & $(.03)$ & $(.03)$ & $(.03)$ & $(.03)$ & $(.03)$ & $(.03)$ & $(.03)$ & $(.03)$ \\
\hline \multirow{2}{*}{ distance ${ }_{\mathrm{ij}}$} & $-1.30^{*}$ & $-1.30^{*}$ & $-1.34^{*}$ & $-1.29^{*}$ & $-1.33^{*}$ & $-1.28^{*}$ & $-1.28^{*}$ & $-1.28^{*}$ & $-1.28^{*}$ & $-1.28^{*}$ \\
& $(.07)$ & $(.07)$ & $(.07)$ & $(.07)$ & $(.07)$ & $(.06)$ & $(.06)$ & $(.06)$ & $(.06)$ & $(.06)$ \\
\hline \multirow{2}{*}{ PS } & $-3.18^{*}$ & $-3.30^{*}$ & $-3.25^{*}$ & $-3.04^{*}$ & $-3.08^{*}$ & $-3.08^{*}$ & $-3.15^{*}$ & $-3.07^{*}$ & $-2.91^{*}$ & $-2.86^{*}$ \\
& $(.11)$ & $(.12)$ & $(.11)$ & $(.12)$ & $(.13)$ & $(.14)$ & $(.16)$ & $(.15)$ & $(.14)$ & $(.15)$ \\
\hline \multirow{2}{*}{ PC } & $-2.97 *$ & $-3.02 *$ & $-3.02^{*}$ & $-3.16^{*}$ & $-3.41^{*}$ & $-2.76^{*}$ & $-2.88^{*}$ & $-2.94^{*}$ & $-3.01 *$ & $-3.04^{*}$ \\
& $(.16)$ & $(.18)$ & $(.19)$ & $(.19)$ & $(.21)$ & $(.17)$ & $(.19)$ & $(.18)$ & $(.18)$ & $(.20)$ \\
\hline \multirow{2}{*}{ ER } & -0.43 & 0.10 & 0.51 & -0.56 & $-1.45^{*}$ & -0.18 & -0.01 & -0.07 & $-0.64 *$ & $-0.73^{*}$ \\
& $(.35)$ & $(.45)$ & $(.46)$ & $(.36)$ & $(.39)$ & $(.23)$ & $(.30)$ & $(.26)$ & $(.22)$ & $(.25)$ \\
\hline Observations & 1038 & 1036 & 1043 & 1041 & 1041 & 1024 & 1024 & 1024 & 1024 & 1024 \\
\hline Adjusted R $\mathrm{R}^{2}$ & 0.75 & 0.72 & 0.75 & 0.75 & 0.75 & 0.75 & 0.71 & 0.73 & 0.74 & 0.73 \\
\hline SEE & 1.240 & 1.401 & 1.303 & 1.285 & 1.313 & 1.208 & 1.384 & 1.274 & 1.240 & 1.313 \\
\hline
\end{tabular}

Notes: Foreign gross products are converted to Canadian dollars with PPP exchange rates from OECD $(1997,1998)$. ER equals the logged ratio of the nominal exchange rate (foreign currency/Canadian dollar) to the PPP exchange rate. All equations include constant terms. The SUR estimates are the results of an SUR where the coefficients on $y_{i}$ and distance are constrained to be equal in each sample period. Standard errors are reported in parentheses. They have been corrected for heteroskadasticity in the least squares estimates. *indicates statistical significance at the $1 \%$ error level. 
two terms: foreign output converted to Canadian dollars with the PPP exchange rate and the deviation of the nominal exchange rate from its PPP counterpart. When this form of (2) is estimated, the results reveal a significant fall in Canada's home bias vis-à-vis the US and a significant rise in its home bias vis-à-vis the other sample countries in the 1990s (Table 5). ${ }^{11}$ The estimated home bias vis-à-vis the US fell from a high of 23-to-1 in 1990 to 17 -to-1 in 1996 while the other measure of home bias rose from 16-to-1 in 1988 to 21-to-1 in 1996. This suggests that regionalization has involved both a reduction of the economic border between Canada and the US and an increase in that between Canada and the other industrial countries.

Two additional caveats deserve mention. First, even though the timing of the changes in Canada's trade biases strongly suggests a role for the FTA, they could be part of longer term trends that predate the free trade area. Because the data only begin in 1988 it is not possible to investigate this by extending the analysis back in time. However Schwanen (1997) reports that during 1988-95 Canada's bilateral trade with the US grew substantially faster than it did during 1981-88 and argues that only part of its acceleration can be attributed to macroeconomic and long-term factors. Second, these results refer to Canada's home and US biases vis-à-vis the industrialized countries and might differ for a broader range of sample countries. However expanding the sample to include Brazil, Korea, Mexico, and Taiwan did not alter the principal findings reported in Table $1 .^{12}$

\section{Conclusions}

This paper finds a substantial home bias in Canada's merchandise trade relative to the US and other industrial countries in the period 1988-96. For the five years examined here, Canada's interprovincial trade averages 19 to 21 times the level of trade between a province and another (non-US) industrial country after controlling

\footnotetext{
${ }^{11}$ In the constrained SUR estimates, a $\chi^{2}$ test of the hypothesis that the coefficient on $P C$ is the same in 1988 and 1996 produces a p-value of 0.059 and a $\chi^{2}$ test that the coefficient on PS is the same in 1990 and 1996 yields a p-value of 0.078 . The estimates in Table 5 include a single term for the deviations from PPP, calculated as the log of the ratio of the bilateral nominal exchange rate (foreign currency/ Canadian dollar) to the relevant bilateral PPP exchange rate derived from $\operatorname{OECD}(1997,1998)$. Including separate exchange rate terms for exports and imports did not alter the coefficient estimates for any of the other variables or the overall fit of the equation.

${ }^{12}$ Outside of the major industrialized economies, these four countries are among Canada's largest trading partners and are the four non-industrialized economies included in Anderson and Smith's (1999) sample.
} 
for the effects of distance, economic size, and adjacency. This home bias is both large in an absolute sense and small in a comparative sense. In an absolute sense, it implies a remarkably large difference between the density of trade within a country's borders and that between countries. ${ }^{13}$ Comparatively speaking, though, the estimate is no larger, on average, than the home bias vis-à-vis the US. This is surprising in view of the close economic and non-economic ties between Canada and the US. Apparently, much of the considerable trade between Canada and the US can be explained by the countries' geographic situation and economic sizes.

However these averages obscure an emerging gap between the two estimates of Canada's home bias. Measured relative to industrial countries other than the US, the home bias increased from about 16-to-1 in 1988 to over 20-to-1 in 1996. No such increase is evident in the home bias measured relative to the US; if it has changed at all, the home bias vis-à-vis the US has fallen over time. The divergent changes in the two measures of home bias equate to a growing US bias in Canada's international trade.

The rise in the US bias coincides with the formation of the FTA, suggesting that the free trade area has been a catalyst for the regional bias in Canada's trade that has emerged in the 1990s. It remains to be seen whether the regional trade bias will continue to grow as the free trade area matures or whether it will broaden to include Mexico in the wake of NAFTA's formation.

Date submitted: September 1999

Final manuscript accepted: May 2000

\section{References}

Anderson, Michael A. and Stephen L. S. Smith (1999), "Canadian Provinces in World

Trade: Engagement and Detachment," Canadian Journal of Economics 32, February, 22-38.

Deardorff, Alan (1998), "Determinants of Bilateral Trade: Does Gravity Work in a Neoclassical World?" in Jeffrey Frankel, ed., The Regionalization of the World Economy, Chicago, University of Chicago Press, 7-22.

Frankel, Jeffrey (1997), Regional Trading Blocs in the World Economic System,

\footnotetext{
${ }^{13}$ These large home biases could be unique to Canada. However Wei's (1996) estimate of Canada's home bias is extremely close to the OECD average, suggesting Canada's home bias is not unusually large. The large home biases could be a function of the level of aggregation and geographic units used in the analysis; the results might differ for disaggregated trade data, other measures of economic exchanges, or smaller geographic divisions. Indeed, Anderson and Smith (1999) find the estimated home bias varies widely by province, as well as by the direction of the bilateral trade flow.
} 
Washington, Institute for International Economics.

Frankel, Jeffrey and Shang-jin Wei (1998), "Regionalization of World Trade and Currencies: Economics and Politics," in Jeffrey Frankel, ed., The Regionalization of the World Economy, Chicago, University of Chicago Press, 189-226.

Helliwell, John (1998), How Much Do National Borders Matter? Washington, D.C. The Brookings Institution.

Helliwell, John (1996), “Do National Borders Matter for Quebec's Trade?" Canadian Journal of Economics 29, August, 507-22.

McCallum, John (1995), "National Borders Matter: Canada-US Regional Trade Patterns"

American Economic Review 85, June, 615-623.

OECD (1998), Main Economic Indicators, Paris, October. , National Accounts, I, Paris.

Schwanen, Daniel (1996), Trading Up: The Impact of Increased Continental Integration on Trade, Investment, and Jobs in Canada, CD Howe Institute Commentary 89, March.

Wei, Shang-jin (1996), "Intra-national versus International Trade: How Stubborn Are Nations in Global Integration?" NBER Working Paper 5531, April.

\section{Appendix 1}

\section{Data Sources and Definitions}

The dependent variable used in the analysis was constructed by the author in the manner described in McCallum (1995). Two primary sources of data were used. The first is a matrix of interprovincial trade, which consists of estimates of merchandise shipments from each province to every other province, along with each province's international exports and imports. These data are from Statistics Canada, downloaded from CANSIM. They were combined with data on provinces' trade with individual states and countries from Statistics Canada, Imports, Merchandise Trade (1988, 1990), Exports, Merchandise Trade (1988, 1990), and similar data for 1992, 1994, and 1996 from Statistics Canada, downloaded from http://strategis.ic.gc.ca. The second data source was used to derive shares of provinces' international exports and imports with each of the states and countries in the sample. The shares were applied to the value of each province's international trade from the matrix of interprovincial trade to arrive at the values used for the dependent variable.

Except for Taiwan, period average exchange rates, countries' gross domestic products, and their populations are from International Monetary Fund, 
International Financial Statistics Yearbook, 1997 and International Financial Statistics, August 1998 and June 1999. The Taiwanese data are from Directorate General of Budget, Accounting and Statistics, Executive Yuan, ROC, http:// www.dgbasey.gov.tw. PPP exchange rates are from OECD, Main Economic Indicators, October 1998 and National Accounts, Volume I, 1997. Bilateral nominal and PPP exchange rates for trade between Canada and countries other than the US were derived from the two relevant bilateral rates against the US dollar.

Gross state products are from Bureau of Economic Analysis, Survey of Current Business, June 1997 and http://www.bea.doc.gov/bea/. State populations are from Department of Commerce, Statistical Abstract of the United States, 1996 and http://www.census.gov/populations/estimates/state/. Provincial gross products are from Statistics Canada, Canadian Economic Observer, Historical Statistical Supplement 1995/96 and http://www.statcan.ca. Provincial populations are from Statistics Canada, National Income and Expenditure Accounts 1984-95 and CANSIM, matrices 6367-6379.

Distances between trading pairs are calculated as the great circle distances; the longitudes and latitudes of the economic centers of each trading pair were used with the Great Circle Distance Calculator at http://www.atinet.org/ steve/cs150/. Appendix 2 lists the cities selected to represent the economic centers. For California and Texas distances were measured as the average distances from each state's two largest cities.

\section{Appendix 2}

\section{Cities Selected to Represent Economic Centers}

\begin{tabular}{llll} 
Province, state & City & State, country & City \\
\hline Alberta & Edmonton & Ohio & Cleveland \\
British Columbia & Vancouver & Pennsylvania & Philadelphia \\
Manitoba & Winnipeg & Tennessee & Nashville \\
Newfoundland & St Johns & Texas & average of Dallas \\
New Brunswick & St John & & and Houston \\
Nova Scotia & Halifax & Vermont & Burlington \\
Ontario & Toronto & Virginia & Richmond \\
Prince Edward Is & Charlottetown & Washington & Seattle \\
Quebec & Montreal & Wisconsin & Milwaukee
\end{tabular}




\begin{tabular}{llll} 
Province, state & City & State, country & City \\
\hline Saskatchewan & Regina & Australia & Sydney \\
Alabama & Birmingham & Austria & Vienna \\
Arizona & Phoenix & Belgium & Brussels \\
California & average of Los Angeles Denmark & Copenhagen \\
& and San Francisco & Finland & Helsinki \\
Florida & Miami & France & Paris \\
Georgia & Atlanta & Germany & Berlin \\
Idaho & Boise & Ireland & Dublin \\
Illinois & Chicago & Italy & Rome \\
Indiana & Indianapolis & Japan & Tokyo \\
Kentucky & Louisville & Netherlands & Amsterdam \\
Louisiana & New Orleans & New Zealand & Auckland \\
Maine & Portland & Norway & Oslo \\
Maryland & Baltimore & Portugal & Lisbon \\
Massachusetts & Boston & Spain & Madrid \\
Michigan & Detroit & Sweden & Stockholm \\
Minnesota & Minneapolis & Switzerland & Zurich \\
Missouri & St Louis & UK & London \\
Montana & Billings & Brazil & Sao Paulo \\
New Hampshire & Manchester & Korea & Seoul \\
New Jersey & Newark & Mexico & average of Juarez \\
New York & New York City & & and Mexico City \\
North Carolina & Charlotte & Taiwan & Taipei \\
North Dakota & Fargo & & \\
& & &
\end{tabular}

